\title{
SIGNIFICANT DOUBT ABOUT THE GOING CONCERN ASSUMPTION IN AUDIT
}

\author{
Adela Socol ${ }^{l}$
}

\begin{abstract}
The purpose of this paper is to survey the going concern principle and its application in auditor's work. The management of an entity is responsible for the assumption of the going concern principle in the compilation of the financial statements. We study the auditor's responsibilities in the audit of the financial statements relating to management's use of the going concern assumption in the preparation of the financial statements. We analyze the events and conditions that may cause significant doubt about the ability of an entity to continue as a going concern.
\end{abstract}

Key words: Professional judgment, Audit evidence, Management's use of going concern assumption.

JEL codes: M42, M41, L21

\section{Introduction}

The importance of development of a system to sustain the professionals - the accountants and auditors - in the going concern assumption are recognized. Professional norms that provide guidance on accounting and audit, issued by International Accounting Standards Board IASB and by International Auditing and Assurance Standards Board IAASB are the major part of this system. Close to the international accounting-auditing standard-setting processes, the professional judgment represents a challenge in comply with international standards and their proper application.

We chose the going concern principle in audit based our approach on the importance of the going concern assumption for the auditor's report and its users. The management's going concern assumption in preparation of the financial statements and the auditor's responsibility in this area are the important tasks for the audit profession, especially in the context of the contemporary financial crisis. Otherwise, since 2001, the famous bankruptcy of some multinational companies (e.g. Enron, Arthur Andersen) suggests the possible hidden signs in auditor's independence and the necessity to improve the audit procedures, inclusively the going concern assumption in audit.

There are multiple internal and external sources of information available for the auditors in the process of establish his opinion regarding the going concern assumption in the preparation of the financial statements of a company. It is important that auditors can use their professional judgment and can decide what procedures and analyses have to apply in drawing the opinion about their clients' going concern situation.

This study intends to analyse a set of quantitative and qualitative criteria that influence the auditors' reasoning in going concern opinion, according to international settlements and Romanian standards in the domain. We studied the main relevant literature and international accounting and auditing settlements that explore the going concern principle, tentatively to understand the auditor decision making and his judgment. In a difficult actual economic environment, the paper intends to explain the basic items of the going concern concept and to apply the concept in the auditor's work, through the checklist of the going concern, according to the Chamber of Financial Auditors of Romania CAFR procedures.

\footnotetext{
1 “1 Decembrie 1918" University of Alba Iulia, Nicolae Iorga Street, 11-13, Alba Iulia, Romania,
} adelasocol@yahoo.com 


\section{Theoretical background}

Studies on the going concern principle are numerous and widespread, the specialized literature offers multiple general well-documented descriptive or much practical approaches of this accounting-audit phenomenon. Research on going concern reveals studies with different topics or hypotheses - bankruptcy and auditor going concern, modification judgments and accounting regulation, the role of the going-concern opinion in valuing companies' stocks, empirical analysis, models and financial ratios to identify the probability of going concern.

Previous research papers described the going-concern principle in audit in terms of connection with the bankruptcies of the companies. Some of these studies are form ' 70 years (Altman and McGough, 1974), but the theme is actual and in the present (Stanley et. al., 2009), (Nogler, 2008). In the first study issued in 2009, the authors investigate whether insider trading surrounding a going concern opinion is associated with the future bankruptcy status of the firm. The study provide evidence that the insider trading patterns of top-level executives within firms receiving a going concern opinion are consistent with inside assessments of the firms' bankruptcy risk. The second study tests whether or not auditor going concern behavior changed significantly or whether the observed change is a transitory effect, as a result of the bankruptcy of Enron, the subsequent demise of Arthur Andersen, and the fraudulent reporting and bankruptcies with came to light in the following 12 months. Another study (O'Reilly, 2010) uses a controlled experiment to test whether financial analysts perceive the auditor's going concern opinion as useful for pricing stocks in a manner that controls for the influence of auditor liability and audit quality and to examine whether the information content of the audit opinion is moderated by market expectations for a specific audit opinion. The evidence presented in this paper suggests that the information content of the auditor's signal about the financial viability of the company as expressed in the audit opinion is significant, independent of any insurance component the audit may provide. Financial analysts in the study estimated significant stock price reductions when the target company received a going-concern opinion.

Kleinman G. and Anandarajan A. consider that firms which receive going concern modified reports from the auditor face adverse consequences including a potential loss of lines of credit (Kleinman and Anandarajan, 1999). They develop empirical analysis on the usefulness of offbalance sheet variables as predictors of auditors' going concern opinions. This is the first study that uses empirical evidence to test the importance of non-financial cues in the choice of report. The authors consider that qualitative variables can be combined with traditional financial indicators of distress to improve the going concern decision process. The literature in the domain contains many approaches of quantitative and qualitative models to identify going-concern assessment. We remark a recent study which consider that a single risk classification of auditors' going concern reporting makes it difficult to establish the appropriateness of their modifications as the majority of auditors' going concern modifications do not necessarily signal failure, and even a firm which receives an adverse opinion could be resurrected by financiers or a new equity commitment (Young and Wang, 2010).

From the legal requirements point of view, accounting approaches of the going concern principle dates since 1975, when International Accounting Standard IAS 1 Disclosure of Accounting Policies (the present Presentation of Financial Statements) described the going concern principle. In compliance with the paragraph 25 of IAS 1, an entity preparing IFRS financial statements is presumed to be a going concern. If management has significant concerns about the entity's ability to continue as a going concern, the uncertainties must be disclosed. If management concludes that the entity is not a going concern, the financial statements should not be prepared on a going concern basis, in which case IAS 1 requires a series of disclosures (IAS 1, par. 25). In the audit domain, the professional standards issued in 1981 and 1988 by American Institute of Certified Public Accountants AICPA prove the importance given to going concern approach in audit (AICPA, 
1981), (AICPA, 1988). The main purposes of these settlements were to establish the auditors' responsibilities in going concern opinion.

In audit, for the periods beginning on or after December 15, 2009, the going concern is based on settlement of the International Standard on Auditing ISA 570 Going concern. According to this regulation, the auditor's responsibility is to obtain sufficient appropriate audit evidence about the appropriateness of management's use of the going concern assumption in the preparation of the financial statements and to conclude whether there is a material uncertainty about the entity's ability to continue as a going concern (ISA 570, par. 6). ISA 570 provides guidance on the objectives of the auditor (par. 9), that have to:

- Obtain sufficient appropriate audit evidence regarding the appropriateness of management's use of the going concern assumption in the preparation of the financial statements;

- Conclude, based on the audit evidence obtained, whether a material uncertainty exists related to events or conditions that may cast significant doubt on the entity's ability to continue as a going concern; and

- Determine the implications for the auditor's report.

\section{Findings and Interpretations}

We intend to develop and describe the basic themes regarding to the professional judgment of the auditors when evaluating the going concern principle:

1. The going concern review period.

2. The audit procedures in going concern review.

3. Possible events or conditions that may cast doubt about going concern assumption.

4. Impact of going concern for auditor's report.

Also, we present a checklist on going concern, possible to be used for auditors in their work, according to Romanian settlements in the domain, issued by Chamber of Financial Auditors of Romania CAFR.

1. The going concern review period. ISA 570 requires auditors to review the management's going concern assumption. The management's going concern assumption period coincide with the period for auditor's judgment. Auditors shall cover the same period as that used by management to make its assessment as required by the applicable financial reporting framework, or by law or regulation if it specifies a longer period. If management's assessment of the entity's ability to continue as a going concern covers less than twelve months from the date of the financial statements, the auditor shall request management to extend its assessment period to at least twelve months from that date.

2. The audit procedures in going concern review. For the auditor professional judgment, the going concern principle is not a simply test of a balance sheet. According to ISA 570 (par. 16), the auditor shall obtain sufficient appropriate audit evidence to determine whether or not a material uncertainty exists through performing additional audit procedures, including consideration of mitigating factors. These procedures shall include:

a) Where management has not yet performed an assessment of the entity's ability to continue as a going concern, requesting management to make its assessment.

b) Evaluating management's plans for future actions in relation to its going concern assessment, whether the outcome of these plans is likely to improve the situation and whether management's plans are feasible in the circumstances.

c) Where the entity has prepared a cash flow forecast, and analysis of the forecast is a significant factor in considering the future outcome of events or conditions in the evaluation of management's plans for future action: Evaluating the reliability of the underlying data generated to prepare the forecast; and Determining whether there is adequate support for the assumptions underlying the forecast. 
d) Considering whether any additional facts or information have become available since the date on which management made its assessment.

e) Requesting written representations from management and, where appropriate, those charged with governance, regarding their plans for future action and the feasibility of these plans.

Audit procedures that are relevant for auditors, may include the following: management.

- Analyzing and discussing cash flow, profit and other relevant forecasts with

- Analyzing and discussing the entity's latest available interim financial statements.

- Reading the terms of debentures and loan agreements and determining whether any have been breached.

- Reading minutes of the meetings of shareholders, those charged with governance and relevant committees for reference to financing difficulties.

- Inquiring of the entity's legal counsel regarding the existence of litigation and claims and the reasonableness of management's assessments of their outcome and the estimate of their financial implications.

- Confirming the existence, legality and enforceability of arrangements to provide or maintain financial support with related and third parties and assessing the financial ability of such parties to provide additional funds.

- Evaluating the entity's plans to deal with unfilled customer orders.

- Performing audit procedures regarding subsequent events to identify those that either mitigate or otherwise affect the entity's ability to continue as a going concern.

- Confirming the existence, terms and adequacy of borrowing facilities.

- Obtaining and reviewing reports of regulatory actions.

- Determining the adequacy of support for any planned disposals of assets.

3. Possible events or conditions that may cast doubt about going concern assumption. Auditors cannot be considered a prophet - they do not predict future events or developments. But the auditors shall consider whether there are events or conditions that may cast significant doubt on the entity's ability to continue as a going concern (ISA 570, par. 10). After auditors identify events or conditions which may affect the going concern assumption, they have to analyze the impact on the company. This listing is not all-inclusive nor does the existence of one or more of the items always signify that a material uncertainty exists. The significance of such events or conditions often can be mitigated by other factors. For example, the effect of an entity being unable to make its normal debt repayments may be counter-balanced by management's plans to maintain adequate cash flows by alternative means, such as by disposing of assets, rescheduling loan repayments, or obtaining additional capital. Similarly, the loss of a principal supplier may be mitigated by the availability of a suitable alternative source of supply.

Table no. 1

Events or conditions that may cast doubt about going concern assumption

\begin{tabular}{|l|l|l|}
\hline \multicolumn{1}{|c|}{ Financial } & \multicolumn{1}{|c|}{ Operating } & \multicolumn{1}{|c|}{ Other } \\
\hline $\begin{array}{l}\text { Net liability or net current liability } \\
\text { position. }\end{array}$ & $\begin{array}{l}\text { Management intentions to } \\
\text { liquidate the entity or to } \\
\text { cease operations. }\end{array}$ & $\begin{array}{l}\text { Non-compliance } \\
\text { capital or other statutory } \\
\text { requirements. }\end{array}$ \\
\hline $\begin{array}{l}\text { Fixed-term borrowings approaching } \\
\text { maturity without realistic prospects } \\
\text { of renewal or repayment; or } \\
\text { excessive reliance on short-term } \\
\text { borrowings to finance long-term } \\
\text { assets. }\end{array}$ & $\begin{array}{l}\text { Loss of key management } \\
\text { without replacement. } \\
\text { Pending legal or regulatory } \\
\text { proceedings against the } \\
\text { entity that may, if } \\
\text { successful, result in claims } \\
\text { that the entity is unlikely to } \\
\text { be able to satisfy. }\end{array}$ \\
\hline
\end{tabular}




\begin{tabular}{|c|c|c|}
\hline Financial & Operating & Other \\
\hline $\begin{array}{l}\text { Indications of withdrawal of } \\
\text { financial support by creditors. }\end{array}$ & $\begin{array}{l}\text { Loss of a major market, key } \\
\text { customer(s), } \\
\text { license, or } \begin{array}{r}\text { franchise, } \\
\text { principal }\end{array} \\
\text { supplier(s). }\end{array}$ & $\begin{array}{l}\text { Changes in law or } \\
\text { regulation or government } \\
\text { policy expected to adversely } \\
\text { affect the entity. }\end{array}$ \\
\hline $\begin{array}{l}\text { Negative operating cash flows } \\
\text { indicated by historical or prospective } \\
\text { financial statements. }\end{array}$ & Labor difficulties. & $\begin{array}{l}\text { Uninsured or underinsured } \\
\text { catastrophes when they } \\
\text { occur. }\end{array}$ \\
\hline Adverse key financial ratios. & $\begin{array}{l}\begin{array}{l}\text { Shortages of important } \\
\text { supplies. }\end{array} \\
\end{array}$ & \\
\hline $\begin{array}{l}\text { Substantial operating losses or } \\
\text { significant deterioration in the value } \\
\text { of assets used to generate cash } \\
\text { flows. }\end{array}$ & $\begin{array}{l}\text { Emergence of a highly } \\
\text { successful competitor. }\end{array}$ & \\
\hline $\begin{array}{lll}\begin{array}{l}\text { Arrears or discontinuance } \\
\text { dividends. }\end{array} & \text { of } \\
\end{array}$ & & \\
\hline $\begin{array}{l}\text { Inability to pay creditors on due } \\
\text { dates. }\end{array}$ & & \\
\hline $\begin{array}{l}\text { Inability to comply with the terms of } \\
\text { loan agreements. }\end{array}$ & & \\
\hline $\begin{array}{l}\text { Change from credit to cash-on- } \\
\text { delivery transactions with suppliers. } \\
\text { Inability to obtain financing for } \\
\text { essential new product development } \\
\text { or other essential investments. }\end{array}$ & & \\
\hline
\end{tabular}

Source: ISA 570, par. A2, 10.

4. Impact of going concern for auditor's report. Auditors have to express their opinion in the auditor's report, in one of five possible audit opinions: Unmodified opinion, Unmodified opinion (but with matter paragraph), Qualified opinion, Adverse opinion, Disclaimer of opinion.

In the next table, we present the auditors' opinion relating to going concern assumption, according to the settlement of ISA 570.

Table no. 2

The conection between going concern assumption and the auditor's opinion

\begin{tabular}{|c|c|c|c|}
\hline $\begin{array}{c}\text { The management's } \\
\text { uses of going concern } \\
\text { assumption }\end{array}$ & $\begin{array}{c}\text { Material uncertainty } \\
\text { (wthether the events or } \\
\text { sonditions constitute a } \\
\text { material uncertainty) }\end{array}$ & $\begin{array}{c}\text { The adequacy } \\
\text { of related } \\
\text { disclosures in } \\
\text { the financial } \\
\text { statements }\end{array}$ & AUDITORS' OPINION \\
\hline Appropriate & Do not exists & Adequate & Unmodified opinion \\
\hline Appropriate & Exists & Adequate & $\begin{array}{c}\text { Unmodified opinion (but } \\
\text { have to include an Emphasis } \\
\text { of mater paragraph in the } \\
\text { auditor's report) }\end{array}$ \\
\hline Appropriate & Exists & $\begin{array}{c}\text { Disclosures are } \\
\text { not made }\end{array}$ & $\begin{array}{c}\text { Qualified opinion or Adverse } \\
\text { opinion }\end{array}$ \\
\hline Inappropriate & Exists & Unimportant & Adverse opinion \\
\hline Inappropriate & $\begin{array}{c}\text { Material uncertainties are } \\
\text { significant to the financial } \\
\text { statements as a whole }\end{array}$ & Unimportant & Disclaimer of opinion \\
\hline
\end{tabular}


We present a professional checklist relating to the going concern principle, according to the Chamber of Financial Auditors of Romania CAFR procedures (CAFR, 2001; CAFR, 2009).

EXAMPLE. CLIENT:.. Year-end:..

\section{Objective of the audit:}

- Offer the assurance that the management's action to elaborate the financial statement according to the going concern is reasonable.

- Correctly provide any concern reasons resulting from going concern approach in the financial statements.

- Correctly evidence information according to which the going concern principle is considered adequate.

Conclusion: Excepting the aspects communicated to the person responsible with the governance, in my opinion, we realize a sufficient assurance of the audit to sustain our conclusion relating to elaboration of the financial statements on the going concern basis.

Signature: .. Date: ...

Table no. 3

GOING CONCERN ISA 570 - Objective of the audit

\begin{tabular}{|c|c|c|c|c|}
\hline No. & Item & Objective & Program & $\begin{array}{l}\text { Initial } \\
\text { Letters } \\
\text { / Data }\end{array}$ \\
\hline 1. & $\begin{array}{l}\text { This Checklist should be completed in planning of an audit } \\
\text { and in engagement conclusion stage. Where it is necessary, } \\
\text { add explanatory paragraphs. }\end{array}$ & No. 3 & & \\
\hline 2. & $\begin{array}{l}\text { If it is possible, obtain copies of previsions regarding to the } \\
\text { Statement of Cash Flows/Budgets and consider if: } \\
\text { - Financial Statements are prepared on going concern basis } \\
\text { and on coherent hypothesis; } \\
\text { - Financial Statements provide adequate proves on firm's } \\
\text { capacity to continue its activity according to the going } \\
\text { concern principle; } \\
\text { - If management's assessment of the entity's ability to } \\
\text { continue as a going concern covers more than twelve months } \\
\text { from the date of the financial statements } \\
\text { - If management's assessment of the entity's ability to } \\
\text { continue as a going concern covers less than twelve months } \\
\text { from the date of the financial statements the auditor shall } \\
\text { request management to extend its assessment period to at } \\
\text { least twelve months from that date }\end{array}$ & No. 1 & & \\
\hline 3. & $\begin{array}{l}\text { If the Statement of Cash Flows or Budgets are not available, } \\
\text { describe the available proves to sustain firm's capacity to } \\
\text { continue its activity according to the going concern principle. } \\
\text { Keep these evidences. }\end{array}$ & No. 1 & & \\
\hline 4. & $\begin{array}{l}\text { If events or conditions have been identified that may cast } \\
\text { significant doubt on the entity's ability to continue as a going } \\
\text { concern, ensure that the following information are proper: } \\
\text { - Management's disclosure regarding to the preparation of } \\
\text { the financial statements on the going concern basis } \\
\text { - Management's disclosure regarding to the principal events } \\
\text { or conditions that may cast }\end{array}$ & No. 1,2 & & \\
\hline
\end{tabular}




\begin{tabular}{|c|c|c|c|c|}
\hline No. & Item & Objective & Program & $\begin{array}{l}\text { Initial } \\
\text { Letters } \\
\text { / Data }\end{array}$ \\
\hline & $\begin{array}{l}\text { significant doubt on the entity's ability to continue as a going } \\
\text { concern; } \\
\text { - Nature of significant doubt; } \\
\text { - Effects of non-applying of the going concern principle; } \\
\text { - Management's disclosure or and management's plans to } \\
\text { deal with these events or conditions; }\end{array}$ & & & \\
\hline 5. & $\begin{array}{l}\text { Make sure that you obtain sufficient appropriate audit } \\
\text { evidence about the entity's ability to continue as a going } \\
\text { concern minimum twelve months from the date of the } \\
\text { financial statements. }\end{array}$ & No. 3 & & \\
\hline 6. & $\begin{array}{l}\text { Consider the second revision of an independent partner if you } \\
\text { plan a non-standard audit report. }\end{array}$ & No. 1 & & \\
\hline 7. & $\begin{array}{l}\text { In the audit report, consider the management's assessment of } \\
\text { the company's ability to continue as a going concern. } \\
\text { Especially, consider your opinion about the going concern } \\
\text { management's assessment or if management refuse to } \\
\text { undertake or to extend their assessment of going concern. } \\
\text { Assure about the adequacy of your opinion from the audit } \\
\text { report. }\end{array}$ & No. 2 & & \\
\hline 8. & $\begin{array}{l}\text { At the date of the auditor's report: There is any additional } \\
\text { information that influences the validity of financial } \\
\text { statements according to going concern principle? }\end{array}$ & No. $1,2,3$ & & \\
\hline
\end{tabular}

Checklist - Going Concern

\begin{tabular}{|l|l|l|l|l|}
\hline No. & \multicolumn{1}{|c|}{ Item } & $\begin{array}{c}\text { Planning } \\
\text { the audit } \\
\text { Yes/No }\end{array}$ & $\begin{array}{c}\text { Finalizing } \\
\text { the audit } \\
\text { Yes/No }\end{array}$ & Comments \\
\hline 1 & Financial & & & \\
\hline 1.1 & Company's liability exceeds assets? & & & \\
\hline 1.2 & Current liability exceeds current assets? & & \\
\hline 1.3 & Is still necessary the agreement regarding to the loans? & & \\
\hline 1.4 & Are there any agreement or accord infringement? & & \\
\hline 1.5 & $\begin{array}{l}\text { Have the company serious problems relating to the } \\
\text { cash or cash flows? }\end{array}$ & & \\
\hline 1.6 & $\begin{array}{l}\text { Record the company losses or problems regarding to } \\
\text { the cash flows after the date of the financial statements }\end{array}$ & & \\
\hline 1.7 & $\begin{array}{l}\text { Registered the substantial sales of the fixed assets } \\
\text { (buildings or land) and there is not the intention to be } \\
\text { replaced? }\end{array}$ & $\begin{array}{l}\text { Negotiates the company the reorganization of its } \\
\text { borrowings? }\end{array}$ & $\begin{array}{l}\text { Registered the company the refuse (or reduction) of } \\
\text { the normal terms of the commercial loans? }\end{array}$ & \\
\hline 1.8 & $\begin{array}{l}\text { Are necessary the major payments of the borrowings } \\
\text { or is necessary refinancing? }\end{array}$ & & \\
\hline
\end{tabular}




\begin{tabular}{|l|l|l|l|l|}
\hline No. & \multicolumn{1}{|c|}{ Item } & $\begin{array}{l}\text { Planning } \\
\text { the audit } \\
\text { Yes/No }\end{array}$ & $\begin{array}{c}\text { Finalizing } \\
\text { the audit } \\
\text { Yes/No }\end{array}$ & Comments \\
\hline 2 & Operating & & & \\
\hline 2.1 & $\begin{array}{l}\text { Is possible that the company do not adequate adapt at } \\
\text { the technological changes or changes of the market? }\end{array}$ & & \\
\hline 2.2 & $\begin{array}{l}\text { Is the company affect by the extern forced reduction of } \\
\text { its labor activity or loss of management or employees? }\end{array}$ & & \\
\hline 2.3 & $\begin{array}{l}\text { Is the company dependent by the some kind of } \\
\text { products that the market is saturated? }\end{array}$ & & \\
\hline 2.4 & $\begin{array}{l}\text { Loss of the major customers or suppliers or } \\
\text { technological evolution that generates a superseded } \\
\text { product? }\end{array}$ & & \\
\hline 3 & $\begin{array}{l}\text { Other } \\
\text { Is the company implicated in activities that may } \\
\text { generate litigations - pending legal or regulatory } \\
\text { proceedings against the entity? }\end{array}$ & & \\
\hline 3.2 & $\begin{array}{l}\text { Is the company implicated in activities with results } \\
\text { that may affect the going concern? }\end{array}$ & & \\
\hline
\end{tabular}

\section{Conclusions}

The paper explains the going concern concept in audit, what it means and what is the conection with the management's going concern assumption from financial settlement. Auditors have to evaluate the management's going concern assesment. The entity's interaction with the auditor is very important to facilitate the identification of possible events or conditions that may cast significant doubt on the entity's ability to continue as a going concern. The significance of these events or conditions is varied from entity to entity, but may be mitigated by other factors. Management elaborates a financial report that gives a true and fair view of the entity's financial position, cash-flows and results. Auditors review the financial report and the incorporated financial statements in order to formulate an opinion and to consider whether all the management's disclosures present a true and fair view of the entity.

\section{References}

1. Altman E., McGought T., 1974. Evaluation of a company as a going-concern, Journal of Accountancy, pp. 50-57.

2. American Institute of Certified Public Accountants AICPA, 1981. The Auditor's Consideration When a Question Arises About an Entity's Continued Existence, SAS No. 34, New York.

3. American Institute of Certified Public Accountants AICPA, 1988. The Auditor's Consideration of an Entity's Ability to Continue as a Going Concern, SAS No. 59, New York.

4. Camera Auditorilor Financiari din România, 2001. Norme minimale de audit, Editura Economică, Bucureşti.

5. Camera Auditorilor Financiari din România, 2009. Manual de standarde internaționale de audit si control de calitate - Audit financiar, Editura Irecson, Bucureşti.

6. Kleinman G., Anandarajan A., 1999. The usefulness of off-balance sheet variables as predictors of auditors' going concern opinions: an empirical analysis, Managerial Auditing Journal, 14/6, pp. 273-285.

7. Nogler G.E., 2008. Going concern modifications, CPA firm size, and the Enron effect, Managerial Auditing Journal, Vol. 23, No. 1, pp. 51-67. 
8. O'Reilly D.M., 2010. Do investors perceive the going-concern opinion as useful for pricing stocks?, Managerial Auditing Journal, Vol. 25, No. 1, pp. 4-16.

9. Stanley J., Todd De Zoort F., Taylor G., 2009. The association between insider trading surronding going concern audit opinions and future bankruptcy, Managerial Auditing Journal, Vol. 24, No. 3, pp. 290-312.

10. Young A., Wang Y., 2010. Multi-risk level examination of going concern modifications, Managerial Auditing Journal, Vol. 25, No. 8, pp. 756-791. 